\title{
SEGMENTATION OF MARKETS IN CENTRAL AND EASTERN EUROPE COUNTRIES WITH THE USE OF THE CMS METHOD ${ }^{1}$
}

\author{
Marcin Salamaga
}

\begin{abstract}
The paper is aimed at a comparative analysis of Central and Eastern European countries regarding the range of effects associated with changes in their exports. The effects of changes in the exports of individual countries will be separated based on the model of constant market share (CMS) developed by Leamer and Stern. The calculated effects: the demand effect, the market distribution effect, the commodity composition effect and the competitiveness effect will enable a detailed assessment of the sources of changes occurring in the exports of individual countries and will, in particular, allow for answering the following question: to what extent may changes in exports be explained by the economic situation in the world trade of individual clusters of commodities, and to what extent do they result from the competitiveness of these countries? The application of the multivariate statistical analysis method for the designated effects will allow for the identification of clusters of countries in a very similar position in the spatial and commodity arrangement, including countries of similar competitiveness of trade.
\end{abstract}

Keywords: decision tree, logistic regression, turnover intention.

JEL Classification: F1, B17, C1.

DOI: $10.15611 / \mathrm{me} .2017 .13 .05$.

\section{Introduction}

The segmentation of foreign markets is one of the key elements in the study of foreign markets. The segmentation of foreign markets brings a range of measurable benefits to enterprises that seek new markets. In particular, it helps adapt the product and the tools of its impact to the needs of consumers, and allows to gain competitive advantage in an international scale. Segmentation brings such an effect thanks to the recognition of potential for activity

\footnotetext{
Marcin Salamaga

Cracow University of Economics

e-mail: salamaga@uek.krakow.pl

ORCID: 0000-0003-0225-6651
}

${ }^{1}$ Publication was financed from funds allocated to Faculty of Management (Cracow University of Economics) within grants to maintain research capacity. 
in the market, determination of the proper conditions of the product development and design of relevant activities for specific segments [Duliniec 1994]. There are various concepts of foreign market segmentation presented in literature, but two approaches are predominant: post hoc portfolio analyses and a priori analyses, but there are also mixed approaches that use market profile variables [Wind 1978; Green 1977; Rao, Wang 1995; Sobczak 2010] and a means-end hierarchical chain approach aimed at testing consumer preferences and motifs [Young, Feigin 1975; Gutman 1984]. In practice, the hybrid or mixed approach to segmentation is frequently used; this is a combination of a priori and post hoc approaches. Usually, it involves a priori macro-segmentation that leads to the emergence of macro segments which are then clustered with the use of other methods to look for homogeneous clusters within macro segments [Dolnicar 2004; Hassan, Craft 2005; Walesiak, Bąk 2000]. The study of literature allows for stating that researchers use various variables that represent, for example, production factors, demand conditions, social and economic climate, indicators of economic development, and others to divide markets into segments. There is no single coherent approach in the existing theoretical concepts of market segmentation and in empirical research that would take account of the contribution of various effects that, on the one hand, result from turnover in international commerce, and, on the other hand, affect the turnover. The knowledge about the share of factors responsible for market absorption, capacity, geographical attractiveness, and competitiveness in commercial transactions may be of key importance to the selection of the market by the exporter.

This article proposes a new approach to post hoc foreign market segmentation using the effects of changes in the turnover in international trade, based on a model of Constant Market Share-CMS. The relevant aggregation of the effects associated with a given market has allowed for the use of a CMS model to assess the attractiveness of markets. Market segments have been separated based on the subjective effects with the use of cluster analysis. The article is aimed at suggesting a new method for market segmentation and at applying it based on the example of the following Central and Eastern European state markets: Bulgaria, Croatia, Czech Republic, Estonia, Hungary, Latvia, Lithuania, Poland, Romania, Slovakia, Slovenia. Eurostat data from Comext database which contains information on foreign trade of the EU states was used in calculations. The study contains data from 2015 and 2016. 


\section{Method of foreign market segmentation}

The adopted method of market segmentation combines a model of constant market share [Tyszyński 1951; Leamer, Stern 1970] with cluster analysis. The CMS model is based on three matrices: $\mathbf{X}^{(\mathbf{0})}$ - matrix of the value of the exports during the base period, $\mathbf{X}^{(\mathbf{t})}$ - matrix of the value of the exports during the analysed period, and $\mathbf{R}$ - matrix of trade dynamic ratios. The specification of the matrices is as follows:

$$
\begin{aligned}
& \mathbf{X}^{(0)}=\left[\begin{array}{cccc}
x_{11}^{(0)} & x_{12}^{(0)} & \ldots & x_{1 n}^{(0)} \\
x_{21}^{(0)} & x_{22}^{(0)} & \ldots & x_{2 n}^{(0)} \\
\ldots & \ldots & \ldots & \ldots \\
x_{m 1}^{(0)} & x_{m 2}^{(0)} & \ldots & x_{m n}^{(0)}
\end{array}\right], \mathbf{X}^{(0)}=\left[\begin{array}{cccc}
x_{11}^{(t)} & x_{12}^{(t)} & \ldots & x_{1 n}^{(t)} \\
x_{21}^{(t)} & x_{22}^{(t)} & \ldots & x_{2 n}^{(t)} \\
\ldots & \ldots & \ldots & \ldots \\
x_{m 1}^{(t)} & x_{m 2}^{(t)} & \ldots & x_{m n}^{(t)}
\end{array}\right], \\
& \mathbf{R}=\left[\begin{array}{cccc}
r_{11} & r_{12} & \ldots & r_{1 n} \\
r_{21} & r_{22} & \ldots & r_{2 n} \\
\ldots & \ldots & \ldots & \ldots \\
r_{m 1} & r_{m 2} & \ldots & r_{m n}
\end{array}\right],
\end{aligned}
$$

where:

$x_{i j}^{(0)}$ - value of the exports of $j$-th product to $i$-th country during the base period,

$x_{i j}^{(t)}$ - value of the exports of $j$-th product to $i$-th country during the analysed period,

$r_{i j}$ - exports dynamics ratio in the scope of $j$-th product in the $i$-th market,

$n$ - number of trade partners (markets),

$m$ - number of commodities (clusters of commodities, industries, etc.).

In his original model, Tyszyński separated the change of share of a specific country in global exports into two elements: a structural factor and a factor that expresses competitiveness. Over time the model was modified and currently its most expanded version proposed by Leamer and Stern [1970] is best known.

The Leamer-Stern-Tyszyński model may be considered from the perspective of foreign markets and commodity clusters. This study is focused on the former perspective. For each market the change in exports may be presented in the following manner [Mynarski 2001]:

$$
\Delta x_{i}=(r-1) \sum_{j=1}^{m} x_{i j}^{(0)}+\left(r_{i}-r\right) \sum_{j=1}^{m} x_{i j}^{(0)}+\left(\sum_{j=1}^{m} r_{i j} x_{i j}^{(0)}-r_{i} \sum_{j=1}^{m} x_{i j}^{(0)}\right)+\left(\sum_{j=1}^{m} x_{i j}^{(t)}-\sum_{j=1}^{m} r_{i j} \sum_{j=1}^{m} x_{i j}^{(0)}\right) .
$$


For the $i$-th market, the fractional effects are as follows:

1. $(r-1) \sum_{j=1}^{m} x_{i j}^{(0)}$ - the demand effect which reflects the impact of global demand on transactions in foreign trade. A positive value of this effect means a favourable situation in the market.

2. $\left(r_{i}-r\right) \sum_{j=1}^{m} x_{i j}^{(0)}$ - the market distribution effect; it demonstrates the impact of market diversification on the change in exports. A positive value of this effect is evidence of the geographic attractiveness of a given market.

3. $\left(\sum_{j=1}^{m} r_{i j} x_{i j}^{(0)}-r_{i} \sum_{j=1}^{m} x_{i j}^{(0)}\right)$ - the commodity composition effect which demonstrates the impact of the diversification in the assortment of commodities on foreign trade turnover. A positive value of this effect means that the structure of the assortment of commodities in a given market is correct.

4. $\left(\sum_{j=1}^{m} x_{i j}^{(t)}-\sum_{j=1}^{m} r_{i j} \sum_{j=1}^{m} x_{i j}^{(0)}\right)$ - the competitiveness effect; it reflects the impact of the competitiveness of the exporting country. A positive value of this effect suggests a relatively high competitiveness of exported commodities.

In the adopted research methodology, the calculated effects for each market are then used to assess the attractiveness of markets by calculating mean shares of effects in the imports to a given market by each importer. The averaged values of shares in effect allows for assessing from an average exporter's perspective:

- whether the economic situation in a given market is favourable,

- whether the market is attractive in terms of location,

- whether it is easy to find the proper assortment composition of commodities in the market,

- whether it is easy to compete in the market in the scope of a specific group of commodities.

A positive share of the proper effect in total imports from a specific direction will, on average, suggest market attractiveness in the aspect to which the effect applies (e.g. global economic situation, adaptation of the assortment composition or easy competition in a given market). Consequently, a positive effect explains an increase in the imports to a given market. A negative share of a specific effect in imports suggests that the market is not attractive in 
a given aspect and results in a decrease in the imports from a specific direction. It should be emphasised that the proposed application of effects calculated using the Leamer-Stern-Tyszyński model is atypical as the model has been constructed for the purpose of assessing the actions of exporters but, as has been demonstrated, the suitable modification of the calculated effects enables the evaluation of the attractiveness of export destination markets. The second stage of the proposed segmentation procedure is the cluster analysis of foreign markets in accordance with the adopted market attractiveness' indicators (shares of effects in the imports of an average importer). The $K$-means method will be used for this. EU countries have been subjected to the segmentation analysis in the range of product clusters classified at the two-digit level of disaggregation of the Standard International Trade Classification - SITC. The survey has been conducted separately for four clusters of goods of varied saturation level of production factors.

Therefore segmentation has been conducted separately for products which are: material intensive, labour intensive, capital intensive, and technologically intensive.

\section{Research results}

The value of the change in exports in each of the 28 EU countries (exporters) was decomposed into four component effects separated in the market system as in formula 2. The destination markets for the exports of a given EU country were the sales markets of the remaining CEE states (Bulgaria, Croatia, Czech Republic, Estonia, Hungary, Latvia, Lithuania, Poland, Romania, Slovakia, and Slovenia). For each of these 11 markets, shares in effect were calculated with the use of the CMS method in the value of imports from each country-EU importer. Figure 1 presents the average shares of the CMS model in the imports to Poland (in \%) in 2016 (per importer) in the cluster of products of varied saturation with production factors.

Figure 1 suggests that the relative ease of competing with these commodities is an elementary growth factor of the imports of material-intensive commodities to Poland. Other important growth factors include the attractiveness of the market (the competitiveness effect accounted for approximately $13.26 \%$ of the imports of an average importer in 2016), the attractiveness of the market (the market distribution effect accounted for approximately $8.22 \%$ of the imports of an average importer), and ease of determining the correct composition of the assortment of commodities (the commodity effect accounted for approximately $2.75 \%$ of the imports of an average importer). The 
market of material-intensive commodities was characterised by a negative demand effect that reduced the level of the imports of an average importer by approximately $6.88 \%$. In the case of labour-intensive commodities, the Polish market is difficult to compete in the range of products in question (the negative competitiveness effect) while the factors that have a positive impact on an increase in imports include world demand for labour-intensive commodities (the positive world demand effect) and increased market diversification affecting turnover (the positive market distribution effect). In the case of capital-intensive commodities, all effects have a favourable impact on imports to Poland. The competitiveness effect which accounts for approximately $16.91 \%$ of an average importer's imports has the greatest impact. When it comes to technologically-intensive commodities, only the commodity composition effect strengthens their imports to Poland (this effect accounts for approximately $2.42 \%$ of an average importer's imports). The remaining effects hinder the inflow of imports and the attractiveness of the Polish market in regard of technologically-intensive commodities is reduced to the greatest extent by the average negative influence of market diversification on the import of commodities in question (the market distribution effected accounts for approximately $-3.14 \%$ of last year's imports).

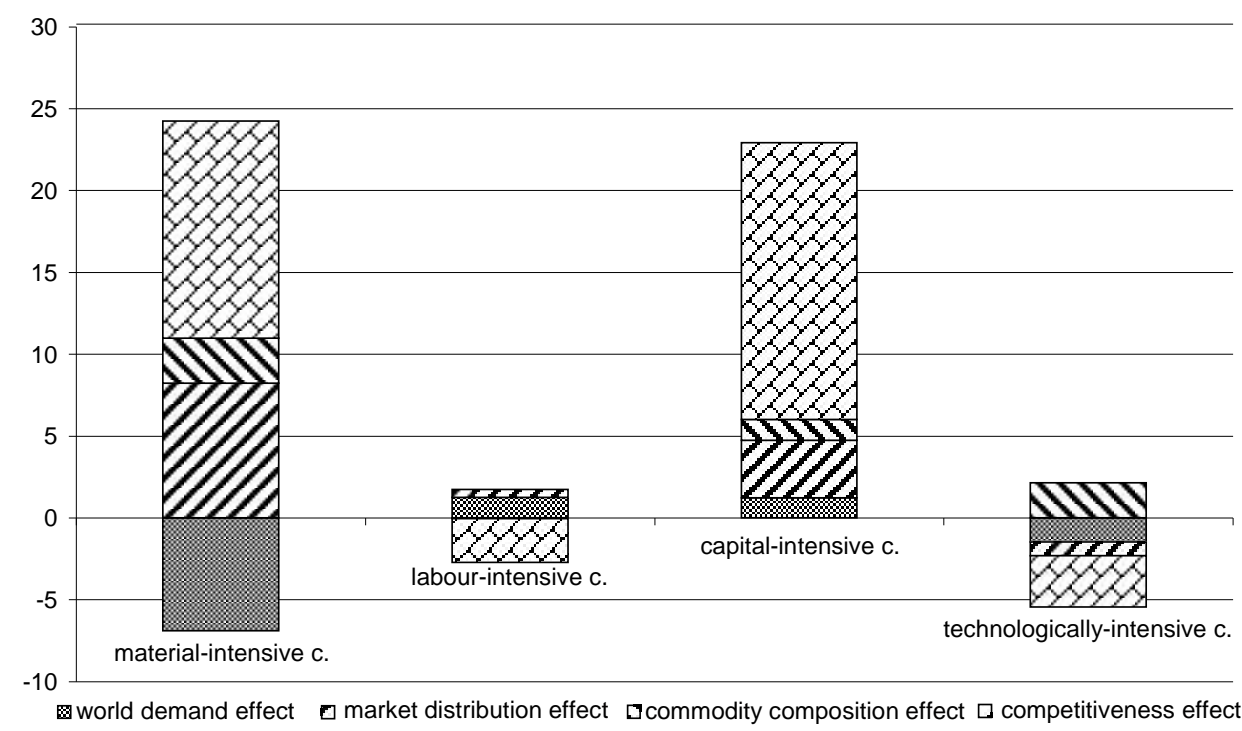

Fig. 1. Average shares of the effects of CS model in the imports to Poland (in \%) in 2016 per importer by products of diverse saturation with production factors

Source: own elaboration. 
The general assessment of the ex post attractiveness of individual Central and Eastern European markets for all commodity clusters was determined based on the value of the average shares of these effects in the imports to a given market per importer in 2016 (cf. Table 1).

Table 1. Average share of effects of the CMS model in the imports (in \%) to individual CEE countries per importer in 2016

\begin{tabular}{|c|c|c|c|c|}
\hline Country - market & $\begin{array}{c}\text { World } \\
\text { demand effect }\end{array}$ & $\begin{array}{c}\text { Market } \\
\text { distribution effect }\end{array}$ & $\begin{array}{c}\text { Commodity } \\
\text { composition effect }\end{array}$ & $\begin{array}{c}\text { Competitiveness } \\
\text { effect }\end{array}$ \\
\hline Bulgaria & \multirow{11}{*}{0.339} & -3.491 & 5.303 & 16.849 \\
\hline Croatia & & -3.409 & 8.085 & 23.962 \\
\hline Czech Republic & & 6.015 & 1.978 & 27.398 \\
\hline Estonia & & 0.748 & 8.408 & 121.498 \\
\hline Hungary & & 4.385 & 2.950 & 2.836 \\
\hline Latvia & & -8.578 & 4.978 & 8.797 \\
\hline Lithuania & & 6.721 & 2.903 & 4.639 \\
\hline Poland & & 8.224 & 2.751 & 13.262 \\
\hline Romania & & 6.711 & 6.708 & 70.624 \\
\hline Slovakia & & -9.135 & 10.025 & 3.088 \\
\hline Slovenia & & 1.722 & 3.493 & 141.750 \\
\hline
\end{tabular}

Source: own elaboration.

When analysing the market distribution effect in individual markets, it may be stated that Poland is the most attractive market for investment (the market distribution effect accounts for approximately $8.2 \%$ of the imports of an average EU importer here). This is followed by Lithuania (with a share of the market distribution effect in the imports of an average importer equal to $6.7 \%)$.

Slovakia and Lithuania turned out to be the least attractive markets for European importers (with negative indicators of the market distribution effect). When it came to Slovakia and Croatia, they were the easiest to obtain the correct commodity composition (in Slovakia the commodity composition effect was the highest and accounted for more than $10.0 \%$ of the average imports from an EU country). The commodity structure was the most difficult to obtain in the Czech Republic.

Slovenia was the easiest country to compete with commodities (the competitiveness effect accounted for approximately $141.8 \%$ of the imports of an 
average exporter there), followed by Estonia. Hungary turned out to be the country where it was most difficult to compete; the next country in this respect was Slovakia. Summing up, it can be concluded that the analysed markets are characterised by considerable diversification both in terms of the calculated effects and between the effects.

The $K$-means method was used in the segmentation in question. The preliminary number of clusters was determined based on the distribution of countries using Ward's method with Euclidean distance. The EU markets were clustered considering the share of individual effects in the imports of an average importer and the results of cluster analysis by commodities of varied levels of saturation with production factors. Taking the above criteria into account for technologically-intensive commodities, the markets were divided into the following four clusters:

cluster 1: Romania, Slovakia, cluster 2: Czech Republic, Slovenia, cluster 3: Croatia, Estonia, Lithuania, cluster 4: Bulgaria, Latvia, Poland, Hungary.

Table 2. Values of shares in effects in the imports by an average importer by segments of markets of technologically-intensive commodities (in \%)

\begin{tabular}{|c|c|c|c|c|}
\hline $\begin{array}{l}\text { Segment } \\
\text { no. }\end{array}$ & $\begin{array}{c}\text { World } \\
\text { demand effect }\end{array}$ & $\begin{array}{c}\text { Market } \\
\text { distribution effect }\end{array}$ & $\begin{array}{c}\text { Commodity } \\
\text { composition effect }\end{array}$ & $\begin{array}{c}\text { Competitiveness } \\
\text { effect }\end{array}$ \\
\hline 1 & \multirow{4}{*}{1.11} & 1.05 & 2.60 & 7.42 \\
\hline 2 & & 2.79 & 3.14 & 107.05 \\
\hline 3 & & 3.73 & 3.29 & 53.19 \\
\hline 4 & & -1.23 & 1.74 & 2.39 \\
\hline
\end{tabular}

Source: own elaboration.

Table 2 suggests that the demand for technologically-intensive commodities was favourable and the demand effect led to the increased imports of an average importer in most market segments: the increase in the imports due to the global effect on for technologically-intensive commodities is around $1.11 \%$ of the imports of an average EU importer in 2016. Segments 2 and 3 were characterised by particular ease of competing with commodities of various importers. What is more, segment 3 was distinguished by the easy matching of the assortment composition of technologically-intensive commodities, 
while segment 2 included also markets which were generally the most attractive for commodities of this type. The most difficult segments for competition in the scope of technologically-intensive commodities are usually segments 1 and 4 . Additionally, segment 4 is the least attractive to such commodities in comparison to other segments.

Next, the Central and Eastern European countries were segmented as a market in the area of capital-intensive goods. Three market segments were separated using the $k$-average method:

cluster 1: Latvia, Slovenia,

cluster 2: Czech Republic, Lithuania, Poland, Romania, Hungary,

cluster 3: Bulgaria, Croatia, Estonia, Slovakia.

Table 3 shows the share of effects in the imports of an average importer according to the separate segments of the capital-intensive goods markets.

Table 3. Values of shares in effects in the imports of an average importer by segments of markets of capital-intensive commodities (in \%)

\begin{tabular}{|c|c|c|c|c|}
\hline $\begin{array}{c}\text { Segment } \\
\text { no. }\end{array}$ & $\begin{array}{c}\text { World } \\
\text { demand effect }\end{array}$ & $\begin{array}{c}\text { Market } \\
\text { distribution effect }\end{array}$ & $\begin{array}{c}\text { Commodity } \\
\text { composition effect }\end{array}$ & $\begin{array}{c}\text { Competitiveness } \\
\text { effect }\end{array}$ \\
\cline { 1 - 3 } 1 & \multirow{3}{*}{3.25} & 2.08 & 3.14 & 17.15 \\
\cline { 1 - 3 } 2 & & 4.08 & 1.36 & 3.29 \\
\cline { 1 - 3 } 3 & & 3.57 & 3.87 & 63.47 \\
\hline
\end{tabular}

Source: own elaboration.

Table 3 suggests that the demand for capital-intensive commodities was favourable and the world demand effect accounted for approximately 3.25\% of the import of an average EU importer in 2016. As compared to other market segments, segment 2 was distinguished by the highest level of the share in market distribution effect, so the segment encompassed the most attractive markets to European importers. Segment 3 was distinguished by easy product competition (segment 1 is in the second position in this respect). Segment 3 was also distinguished by the greatest ease in matching the assortment composition of capital-intensive commodities.

The clustering of the Central and Eastern Europe countries using the $k$-means method in the area of labour-intensive goods gives the following segments:

cluster 1: Bulgaria, Lithuania, Slovakia, cluster 2: Croatia, Czech Republic, Slovenia, cluster 3: Estonia, Latvia, Poland, Romania, Hungary. 
Table 4 shows the share of effects in the imports of an average importer according to the separate segments of the labour-intensive goods markets.

Table 4. Values of shares in effects in the imports of an average importer by segments of markets of labour-intensive commodities (in \%)

\begin{tabular}{|c|c|c|c|c|}
\hline $\begin{array}{c}\text { Segment } \\
\text { no. }\end{array}$ & $\begin{array}{c}\text { World } \\
\text { demand effect }\end{array}$ & $\begin{array}{c}\text { Market } \\
\text { distribution effect }\end{array}$ & $\begin{array}{c}\text { Commodity } \\
\text { composition effect }\end{array}$ & $\begin{array}{c}\text { Competitiveness } \\
\text { effect }\end{array}$ \\
\cline { 1 - 3 } 1 & \multirow{3}{*}{1.26} & 3.72 & -0.01 & 122.14 \\
\cline { 1 - 3 } \cline { 3 - 5 } & & 3.57 & 0.54 & 17.69 \\
\cline { 1 - 3 } \cline { 3 - 5 } & & 1.29 & 0.24 & -1.98 \\
\hline
\end{tabular}

Source: own elaboration.

Table 4 suggests that the demand for labour-intensive commodities was favourable and the world demand effect accounted for approximately $1.26 \%$ of the imports of an average EU importer in 2016. As compared to other market segments, segment 1 was distinguished by the highest level of the share in market distribution effect, so the segment encompassed the most attractive markets to European importers. Segment 1 was also distinguished by easy product competition (segment 2 is in the second position in this respect). Segment 2 showed the greatest ease in matching the assortment composition of labour-intensive commodities.

Next, the Central and Eastern European countries were segmented as a market in the area of material-intensive goods. Three market segments were separated using the $k$-means method:

cluster 1: Romania, Slovenia,

cluster 2: Bulgaria, Latvia,

cluster 3: Czech Republic, Estonia, Poland,

cluster 4: Croatia, Lithuania, Slovakia, Hungary.

Table 5 shows the share of effects in the imports of an average importer according to the separate segments of the material-intensive goods markets.

Table 5. Values of shares in effects in the imports of an average importer by segments of markets of material-intensive commodities (in \%)

\begin{tabular}{|c|c|c|c|c|}
\hline $\begin{array}{c}\text { Segment } \\
\text { no. }\end{array}$ & \multirow{2}{*}{$\begin{array}{c}\text { World } \\
\text { demand effect }\end{array}$} & $\begin{array}{c}\text { Market } \\
\text { distribution effect }\end{array}$ & $\begin{array}{c}\text { Commodity } \\
\text { composition effect }\end{array}$ & $\begin{array}{c}\text { Competitiveness } \\
\text { effect }\end{array}$ \\
\hline \multirow{2nnyy}{*}{1} & \multirow{3}{*}{-6.88} & 4.13 & 4.66 & 148.14 \\
\cline { 1 - 3 } \cline { 4 - 5 } & & -5.70 & 4.45 & 14.56 \\
\cline { 1 - 3 } & & 4.90 & 3.88 & 53.58 \\
\cline { 1 - 3 } & & -0.26 & 5.39 & 9.97 \\
\hline 4
\end{tabular}

Source: own elaboration. 
Table 5 suggests that the demand for material-intensive commodities was not favourable and the demand effect led to the decreased import of an average importer in all market segments. Segments 1 and 3 were characterised by particular ease of competing with the commodities of various importers. Segment 4 was distinguished by the easy matching of the assortment composition of material-intensive commodities while segment 3 (to which Poland belonged) covered also markets which were generally the most attractive for commodities of this type. The most difficult segments for competition in the field of material-intensive commodities are usually segments 3 and 4. Additionally, segment 2 is the least attractive to such commodities in comparison to other segments.

\section{Conclusions}

The article presents the proposal of market segmentation using the example of Central and Eastern Europe states with the use of the model of constant market share. Such segmentation allowed for considering the different effects associated with the change in foreign trade turnover: the economic situation in a given market, its geographic attractiveness, the ease of obtaining the desired selectivity, and the ease of competing with commodities. Thanks to the proper transformation of the effects calculated with the Leamer-SternTyszyński method, it was possible to assess which factors affected an increase (or decrease) in the import to individual markets and to what extent. Such a combination of the obtained results with the cluster analysis allowed for market segmentation into segments composed of CEE countries as similar to each other as possible in terms of the analysed effects. The review of the obtained results suggests the considerable diversification of effects between countries and groups of commodities of different saturation with production factors. The adopted research approach does not take account of, for example, the profile variables of markets (the economic development level, affluence of society, etc.) and is based only on the effects associated with the change in turnover. This means that, for example, the attractiveness of the foreign market is measured in a different way than in the case of traditional methods. However, it seems that the presented proposal is an interesting alternative to the approaches to market segmentation existing in the literature. The presented results refer to the effects generated in commercial transactions in 2016 and they should be treated as an introduction to further research covering a longer time perspective and possibly trade with non-EU partners (the results presented in this article only refer to intra-community trade or intra-community transactions). 


\section{Bibliography}

Dolnicar S. (2004). Beyond “commonsense segmentation" - A systematic of segmentation approaches in tourism. Journal of Travel Research. No 42(3).

Duliniec E. (1994). Badania marketingowe w zarzadzaniu przedsiębiorstwem. PWN. Warszawa.

Green P.E. (1977). New approach to market segmentation. Business Horizons. No 20.

Gutman J. (1984). Analyzing consumer orientations toward beverages through means-end chain analysis. Psychology \& Marketing, No 1(3/4).

Hassan S.S., Craft S.H. (2005). Linking global market segmentation decisions with strategic positioning options. Journal of Consumer Marketing. No 2.

Leamer E., Stern R. (1970). Quantitative International Economics. Aldine Publishing Co. Chicago.

Mynarski S. (2001). Badania rynkowe w przedsiębiorstwie. Wydawnictwo Akademii Ekonomicznej w Krakowie. Kraków.

Rao Ch.P., Wang Z. (1995). Evaluating alternative strategies in standard industrial markets. European Journal of Marketing. No 2.

Sobczak E. (2010). Segmentacja rynków zagranicznych. Wydawnictwo Uniwersytetu Ekonomicznego we Wrocławiu. Wrocław.

Tyszyński H. (1951). World trade in manufactured commodities, 1899-1950. The Manchester School of Economic and Social Studies. No 19.

Walesiak M., Bąk A. (2000). Conjoint analysis w badaniach marketingowych, Wydawnictwo Akademii Ekonomicznej we Wrocławiu. Wrocław.

Wind Y. (1978). Issues and advances in segmentation research, Journal of Marketing Research. No 3.

Young S., Feigin B. (1975). Using the benefit chain for improved strategy formulation. Journal of Marketing. No 39 . 